\title{
JUDICIAL APPROACH TO THE PETROLEUM AND NATURAL GAS LEASE
}

\author{
W. H. HURLBURT*
}

I propose to consider very briefly the approach of the American courts to the petroleum and natural gas lease. I propose next to consider Canadian cases relating to other types of contract and Canadian cases relating to oil and gas leases in order to compare the judicial approach in these different cases. I propose then to consider whether there are any conclusions to be drawn.

Oil and gas law has had a much longer period of development in the United States. The American law influences Canadian practice and appears to influence Canadian judicial decisions. The American law therefore makes a convenient starting point.

Summers ${ }^{1}$ says that the American courts have on many occasions said that the lease should be construed in favour of the lessor and against the lessee. He says that there are two main reasons for making the statement.

The first reason is that the American courts have in general taken the position that the whole purpose of the lease transaction is to procure development of the property, and they have construed the lease accordingly. Summers questions the validity of this policy of the law in view of two developments. The first is the growth of conservation policies which indicate a public policy which is not necessarily the policy of development. The second is the practice of paying a substantial bonus on the granting of the lease. This bonus itself is an objective of the lessor so that development is not the only objective.

The second reason is that the lease, in the great majority of cases, is prepared by the lessee and tendered by the lessee for execution by the lessor. The general rule of interpretation is that a contract is to be construed against the party who tenders it for execution by the other party.

The opinion of Summers is that it is not correct to say as a general rule of interpretation that the lease is to be construed in favour of the lessor and against the lessee; his opinion is that the "development" theory results in the lease being construed against a lessee who does not develop; and that construction against the party tendering the contract results in a construction adverse to a lessee who tenders the contract for execution.

Summers points out that the court does not have the power "to place a different interpretation upon the contract on grounds of policy that it would be better for the lessor or landowners to have the contract different". He says that this rule of construction (that the expressed intent of the parties is controlling) does not conflict with the rules previously referred to, since the rules previously referred to apply only when there is uncertainty and ambiguity on the face of the lease. He points out however that not all courts have observed the distinction.

Summers mentions two other propositions which are relevant here.

- Morrow, Hurlburt, Reynolds, Stevenson \& Kane, Edmonton, Alberta.

1 Oil and Gas, Vol 2, pp. 484 and following. 
The first is that if both parties act on one interpretation of a contract, the court will adopt that interpretation. However, this propostion does not apply where the meaning of the contract is plain.

The second is that "optional" leases will normally be construed against the party not bound, e.g., a lease with an "unless" clause alone, or a lease with a "drill or pay" clause coupled with the right to surrender.

The foregoing is of course only a paraphrase of what Summers has to say, but will, I hope, provide some background for what follows.

Canadian courts have considered some of these rules of interpretation. I will deal firstly with some examples of cases relating to contracts other than the oil and gas lease, the examples, for the most part, being drawn from decisions of the Supreme Court of Canada, and of the Appellate Division of the Supreme Court of Alberta.

The Supreme Court of Canada has recognized that surrounding circumstances and the objects of a contract should be considered in construing the contract. For example, in Toronto Railway Company v. City of Toronto, ${ }^{2}$ the Railway Company was granted the exclusive right and privilege of using and working street railways "in and upon the streets of the said city". The City could direct the Company to extend its street railways in the city, although the Company could abandon its exclusive rights if it did not wish to comply. The question was whether the Company's obligation to extend its lines applied to the city as it stood at the date of the agreement or the city as it stood after annexation of additional area. Sedgewick J. said at p. 434:
"In construing an instrument in writing, the court is to consider what the facts were in respect to which the instrument was framed, and the object as appearing from the instrument, and taking all these together it is to see what is the intention appearing from the language when used with reference to such facts and with such an object, and the function of the court is limited to construing the words employed; it is not justified in forcing into them a meaning which they cannot reasonably admit of. Its duty is to interpret, not to enact. It may be that those who are acting in the matter, or who either framed or assented to the wording of the instrument, were under the impression that its scope was wider and that it afforded protection greater than the court holds to be the case. But such con- siderations cannot properly influence the judgment of those who have judicially to interpret an instrument. The question is not what may be supposed to have been intended, but what has been said. More complete effect might in some cases be given to the intentions of the parties if violence were done to the language in which the the instrument has taken shape; but such a course would on the whole be quite as likely to defeat as to further the object which was in view."

The Privy Council (1907 A.C. 315) approved the reasoning of Mr. Justice Sedgewick.

In 1917, however, the Supreme Court of Canada held that a franchise granted by the City of Calgary to Canadian Western Natural Gas Co. applied to the whole of the City, including later extensions (City of Calgary v. Canadian Western Natural Gas Co.) ${ }^{3}$ The distinction appears to be that in the Toronto case the court was considering whether or not an obligation could be imposed on the utility company to extend its tracks wherever the City should extend itself, while in the Calgary case they were concerned more with the extension of a right to supply than the imposition of an obligation. There was a furthér point taken which was that a later amending agreement appeared to refer to the extended city as it existed at the

2 (1906) 37 S.C.R. 430 .

8 (1917) 56 S.C.R. 117. 
date of amendment. The two Judges who had taken part in the Toronto decision (Davies and Idington JJ) vigorously dissented.

Shortly thereafter the same Court dealt with an agreement by a gas producer to supply a distribution company with gas for the City of Chatham. (Union Natural Gas v. Chatham Gas Co.)" They held on this occasion that the contract was for sale of gas only for the city as it existed at the date of the contract, and not later. In this case, however, it was possible for the Court to find that, on looking at the whole contract, including the recitals, there was an identification of the system as it existed at the time of the agreement. However, the Court also distinguished the Calgary case on the grounds that the contract in the Chatham case was a private contract for the sale of gas, as opposed to a franchise. A municipal corporation might reasonably be taken to be dealing with whatever area should from time to time be within its jurisdiction, but the conditions in a franchise contract would probably be unsuitable in another type of contract. Fitpatrick C.J. at p. 256 quotes the following well known passage from the reasons for judgment of Lord Loreburn in Tamplin S.S. Co. v. Anglo-Mexican Petroleum Co.:.

"A court can and ought to examine the contract, and the circumstances in which it was made, not of course to vary, but only to explain it, in order to see whether or not from the nature of it the parties must have made their bargain on the footing that a particular thing or state of things would continue to exist."

A further example of the court looking to the surrounding circumstances is the decision of the Appellate Division in Structure Oil and Gas Co. Ltd. v. Royalite Oil Co. Ltd. ${ }^{6}$ Structure's gas was delivered to Royalite which extracted the natural gasoline and paid for it. The agreement permitted Royalite to sell Structure's residue gas to Canadian Western and provided for payment by Royalite to Structure. Royalite, however, had the right to sell its own gas first, and had an adequate supply of gas. The parties knew that it was an inevitable result of the processing that Structure's gas would become mixed in a small degree with Royalite's gas so that it was not possible for Royalite to deliver its own gas without a slight admixture of Structure's gas. Since the parties knew that the mixing was inevitable, the Court held that (so long as Royalite had residue gas in excess of Canadian Western's requirements) all the gas sold to Canadian Western was to be regarded as the gas of Royalite despite the admixture of Structure's gas; this, though mixing of gases was not mentioned in the agreement.

It may therefore be taken to be good law that Canadian courts, in construing a contract, should look at the circumstances surrounding execution of the contract and the objects which are to be attained by it.

It should also be noted that the Structure case looks to the subsequent conduct of the parties as a further reason for the conclusion arrived at. Ewing J.A., at p. 60, points out that payments were made and accepted without complaint from month to month for the gasoline extracted from the gas, both before and after commencement of the action. He further points out that some residue gas was purchased by Royalite and paid for in accordance with the agreement. 
Ewing J.A. said at p. 61:

"In my view it is a fair inference from the evidence that the construction which Royalite has always put upon the words of the contract was the only construction which was in the mind of the trustee when the contract was signed. The trustee undoubtedly knew the construction which Royalite placed upon the contract and that Royalite was continuing to act upon the construction without any notice of any claims based upon another construction."

"These are circumstances which the Court is entitled to take into consideration in construing the contract at this date."

The Canadian courts are also committed to the proposition that the contract should be construed as a whole and that clauses should be read together. For example, in Ottawa Electric Co. v. St. Jacques ${ }^{7}$ a contract for the supply of electricity to a consumer was to remain in force for a stated period and thereafter until cancelled by one party. A later clause however provided that, if the customer renewed his lease of the property being supplied, the contract was to remain in force. The Supreme Court of Canada held that it was not right to do as the Court of Appeal had done and to construe the contract as being valid during the term of the renewal lease only until cancelled in writing, since the provision for cancellation would virtually eliminate the provision for continuation during the renewal of the lease. The Court held that in order to reconcile the clauses, the provision for cancellation must be taken to apply only until the renewal lease was obtained.

Similarly, in the Chatham case referred to above, the Court in construing the reference to the city, looked at recitals referring specifically to the existing distributing system and used in construing the words of the contract itself.

Canadian courts have also considered the proposition that a contract, in case of uncertainty, should be construed against the party tendering it for execution.

For example, in Cook v. Anderson ${ }^{8}$ Frank Ford J.A. said at p. 672:

"It was argued also that as it is said the agreement for sale was drawn by the solicitor for the vendors and that as it is said the purchaser had no solicitor acting for him any doubt as to its interpretation should be resolved against the vendors. The evidence put in by the respondents does not bear out the contention that the draftsman was the solicitor for one and not the other. It goes no further than that he had done some work for the vendors and the document itself bears evidence that the solicitor acted for both vendors and purchaser. Even if the rule as to deeds being construed in favour of a grantee and most strongly against the grantor applies to such a document, it must be remembered that the rule is only applied so far as such a construction may be properly given; and apart from the evidence negativing the suggestion that the vendors' solicitor prepared it and offered it to the purchaser for execution it must be born in mind that the maxim verba fortius accipiuntur contra proferentem is to be applied only when all other rules of construction fail."

It will be seen that he would not give much scope to the principle of interpretation "contra preferentem".

The proposition is also mentioned in the Chatham case at p. 259: "The contract is interpreted as against him who has stipulated and in favour of him who has contracted an obligation."

A slightly different approach, but one which may provide a respectable philosophical basis for the proposition, is that expressed by Newcombe J. in A. R. Williams Machinery Co. Ltd. v. Moore ${ }^{9}$ where he quotes Black- 
burn J. as saying, "the language used by one party is to be construed in the sense in which it would be reasonably understood by the other." The Williams case, however, was one of an informal contract based on correspondence and telegrams.

The Williams case also lays down the proposition that the Court can take into account extrinsic facts that the parties had in mind when they entered into the contract, referring to the authority of Lord Watson in Barrell v. Dryer. ${ }^{10}$

Perhaps this somewhat random review of cases involving interpretation of contracts other than oil and gas leases might usefully end with the judgment of the Judicial Committee of the Privy Council in Northern Ontario Power Company Limited v. LaRoche Mines Limited.11

In the Northern Ontario case, the power company contracted to supply (subject to the right to discontinue on $\mathbf{3 0}$ days notice and subject to a "force majeure" clause), and the customer contracted to purchase from the company, all the power required in connection with two mining properties. The contract was to extend "for the mining life of the properties". The customer later, during the mining life of the properties, sold the properties and went into liquidation. The court had to decide whether the contract remained in force, being particularly concerned with a covenant by the customer that no system of electricity other than that furnished by the power company was to be used in the mines so long as the power company was able and ready to supply the needed electricity. The contract consisted of a printed form containing general and special conditions with blanks filled in to deal with the particular customer. The Judicial Committee held that the assignment of the mining properties terminated the customer's obligations under the contract. The following passages illustrate the general tenor of the reasons for judgment:

"The question of construction their Lordships find more difficult, the difficulty arising from the structure and language which the power company has chosen to employ in framing its standard forms. The contract presents certain features to which attention must be called. There is no definition clause extending the meaning of the word "consumer." It means throughout, and means only, La Roche Mines."

"The question is not free from difficulty, but, after a careful consideration of the arguments presented, their Lordships think that the latter view is the correct view, and not the former. The former view attributes to the parties an intention to impose and to assume a most unusual liability-namely a liability in respect of property which the party liable neither occupies, owns or controls. It would require very plain words to establish such an intention. On the other hand, there is every indication that the contract is dealing with the supply of power to La Roche Mines while in personal occupation, ownership or control of the property. Thus, as pointed out, there is no extended definition of "consumer". It means La Roche Mines only. The contract is not assignable, except with leave. If an effective assignment were to tak place, the assignee would then become the consumer, for the purposes of the contract. The current is to be used by the consumer only. So read, the contract becomes intelligible, and imposes no extraordinary obligations. The consumer (whether $\mathrm{La}$ Roche Mines or a permitted assign of the contract) is bound while in occupation, ownership or control of the property, to observe both the positive provisions in regard to power supplied and the negative provision against getting power elsewhere. When, however, as has happened, La Roche Mines ceased to occupy, own or control the property, and no one became by assignment the consumer under the contract, the contract necessarily came to an end."

The case is an example of interpretation by reference to the detailed wording of the contract. 
It should now be worthwhile to look at the approach of the courts to various problems arising out of oil and gas leases. In view of the great development of the oil and gas industry and of its associated problems in recent years, decisions more than twenty years old do not appear to be too relevant. In order to keep the discussion within bounds, I will refer only to judgments of the Supreme Court of Canada and the Appellate Division. A chronological discussion, while somewhat disjointed, may give the best impression of any movement which is taking place.

Thus limited, the discussion commences with the decision of the Supreme Court of Canada in Mercury Oils Ltd. v. Vulcan-Brown Petroleums Ltd. [1943] S.C.R. 37. The lease in question contained a development clause requiring the operator to drill a second well within twelve months of the drilling of the first well, upon pain of being deemed to have abandoned the property except the first well and the five acres surrounding it. The lease also required that operations be carried on in compliance with the statutes and regulations. Supervening regulations prohibited the granting of a license for a well within $\mathbf{4 4 0}$ yards of a producing well, so that there was no place on the 40 -acre plot for the second well. The lessee applied for a license and was refused. It was nevertheless held that the lease remained in effect. The Court read the provisions together and concluded the Plaintiff was not obliged to drill a second well where the regulations made it illegal to do so. Hudson J. for himself and three other Judges, said at p. 41:

"Reading all of these provisions together as we must, can it be said that the plaintiff is in default within the contemplation of clause 28? I do not think so."

"The present is not a case of frustration or of unjust enrichment. There is no total failure of consideration. The plaintiff has paid the money rental in the past and is under an obligation to pay it in the future. The plaintiff is, so far as we know, operating the first well and paying the defendant the royalty on production provided for by the sublease. Nor is it shown that there is any special hardship imposed upon the defendant. It does not appear that the defendant could get a license to drill where the plaintiff has failed. If the regulations are altered to permit the drilling of another well, then both parties will profit. The defendant will get the royalty; plaintiff the remaining share of the profits."

Presumably the fact that the lessee under one covenant was obliged to drill and under another covenant was obliged to obey the law distinguishes this case from the Gibbard case (infra). It would however be equally consistent with the general view that, the maximum permissible development having taken place, the contract should then be construed in favour of the lessee who has put up his money and not in favour of the lessor who has had the benefit of the lessee's operations. The decision appears to embody a somewhat more liberal view than the more recent decisions.

In 1952, the Appellate Division considered the effect of an "unless" clause and held that the lease provided for its own termination upon failure to comply with the delay rental provisions, a termination which (in the aesthetically unfortunate phrase accepted by the Court) clicks. Since there was an automatic termination there was no grounds for relief against forfeiture (Eastcrest Oil v. Strohschein) ${ }^{12}$. The results in the particular case is consistent with the "development" theory, as the lessee was trying to hold the land without development, though it is also consistent with an uncritical acceptance of the American authority relied on.

12 Eastcrest Oil v. Strohschein (1952) 4 W.W.R. (N.S.) 553. 
The proposition that the "unless" clause works automatically has been accepted in later discisions without further examination, although in the later cases there had been development. It may be that the direction of the law has been influenced by the circumstance that the first important case on the "unless" clause was the Strohschein case rather than, say, the Kininmonth case.

Relief against forfeiture is an important area in the law which is not dealt with in the more recent cases, and which therefore justifies some attention at this point. The Appellate Division in the Strohschein case explicitly refrained from deciding whether jurisdiction to grant relief against forfeiture exists in the case of oil and gas leases, and referred to a similar position taken in Wetter v. New Pacalta Oils. ${ }^{14}$ The question was argued again in Oil City Petroleums (Leduc) Ltd. v. American Leduc Petroleums $L t d . .^{15}$ This case involved a contract between oil operators rather than an oil and gas lease, but it was argued by the appellant that relief against forfeiture should be granted. The Supreme Court of Canada assumed without deciding that there was jurisdiction to grant relief, and held that there was no grounds for relief.

There does not seem to be any conclusive authority either way, but I think that the better view is that in a proper case a court can grant relief against forfeiture of an oil and gas lease, but, in view of the nature of the industry, should be reluctant to do so unless it can be demonstrated that the default and the time involved in litigation will not injure the lessor.

The judgment of the Appellate Division in Canadian Fina Oil v. Paschelk ${ }^{16}$ as delivered by Porter J.A., is an interesting departure from the usual dry and dispassionate analysis of the structure and language of the contract. The question was whether a cheque mailed on the anniversary of the granting of the lease was mailed within one year from the date of the lease so as to prevent the automatic termination brought about by the "unless" clause. Porter J.A. at p. 263 somewhat indignantly repelled the suggestion that judicial notice could not be taken of the fact that time is of the essence in the oil business in view of the long history of the business in the Province. He says that the lessee would have been shocked if it had been told that it could not go on to the land on the date of signature and concludes that that day was the first day of the term so that the first year expired with the day before the anniversary. By using the rapid fluctuation of value as a basis for interpretation, Porter J.A. was looking to the object of the lease and the circumstances surrounding its execution. The construction appears to be against the lessee, and may be based on something like the "development" theory.

Some comment should be made at this point, somewhat out of chronology, on Crommie v. California Standard Company.17 This was a judgment of Milvain J. which was affirmed by the Appellate Division and by the Supreme Court of Canada. One of the arguments advanced by the Plaintiff was that the lease in question was unconscionable, contrary to representations by the Defendant's agent that the lease was a fair agree-

\footnotetext{
18 (1946), 47 W.W.R. 437.

14 (1951) 2 W.W.R. (N.S.) 290 at 294

15 1952) 3 D.L.R. 557.

16 (1957) 21 W.W.R. 260.

17 (1938) W.W.R. 447.
} 
ment and would give fair and reasonable protection to the land owner in certain respects. Milvain $\mathrm{J}$ rejected this argument saying:

"It is my view of the law that in order to make such a contention stand up, the plaintiff must establish the existence of a relationship between the parties to the agreement which places the plaintiff in a position subservient to that of the defendant."

He held that the Plaintiff was not in such a position.

While this statement is directed to the question whether or not the lease could be rescinded, it may at least indicate that the law, apart from any question as to its application, is the same in oil and gas lease cases as in other cases.

We now come to the four recent cases which have given rise to a feeling that the lot of a lessee is not entirely a happy one. These areShell Oil Company v. Gunderson ${ }^{18}$; Shell Oil Company v. Gibbard ${ }^{19}$; CanadaCities Service v. Kininmonth ${ }^{20}$; and Canadian Superior Oil v. Kanstrup. ${ }^{21}$ In each of these cases the lessee claimed to be entitled to an extension of the primary term under an "unless" lease; in each case the lessee was unsuccessful.

In the Gunderson case, Shell Oil Company purported to pool the Gunderson quarter with the other three quarters in the same section, there being a shut-in gas well on one of those quarters. The section as a whole was to constitute a "drilling unit" and Shell purported to keep the Gunderson lease alive by paying the royalty provided for a shut-in gas well. The clause dealing with this royalty, however, referred to a well on "the said land" and Porter J.A. pointed out that these words meant only the Gunderson quarter. Further, it was only drilling operations on or production of leased substances from "the said lands" that would extend the clause. There appears to be some indication in his judgment (with which Johnson J.A. concurred, and with which Ford C.J.A. concurred subject to some additional comments) that he considered the result proposed by the lessee unreasonable.

In the Supreme Court of Canada, Martland J. made a similar point with regard to the use of the phrase "said lands". He also analyzed the matter further and pointed out that drilling operations on other lands in the pool would only continue the lease if they were of the kind defined in the proviso to the habendum clause, namely, drilling operations "after the expiration of the 5-year term." He goes on to say that this proviso "takes effect only if the lease has been extended as a result of production and if, when production ceases a lessee is then engaged in drilling operations."

In the Gibbard case, Shell tried to pool the remaining three quarter sections remaining to them after the loss of the Gunderson quarter. They did this, however, at a time when the well on the north east quarter (which was not the Gibbard quarter section) had gone into production. The difficulty here was that the pooling clause in the lease conferred the right to pool only "when such pooling or combining is necessary in order to conform with any regulations or orders of the Government of the Province of Alberta or any other authoritative body". Both the Appellate Division and the Supreme Court of Canada held that there was no need

18 (1960) S.C.R. 425 (S.C. Can.) (1959) 28 W.W.R. 506 (C.A.).

10 (1961) S.C.R. 725 (S.C. Can.) (1961) 34 W.W.R. 117 (C.A.).

21 (1964) 47 D.L.R. (2d) 1 (S.C. Can.), 43 D.L.R. (2d) 261 (C.A.) 
for the lessee to pool if it did not want to; it could refrain from producing gas from the well. It will be observed that the requirement of giving literal interpretation to the contract on the one hand, and the requirement of construing any doubt against the person tendering the contract, both appear in the following passage from the judgment of the Supreme Court of Canada as delivered by Locke J. at pp. 731-2:

"The difficult question to determine is whether, in the circumstances in this case, pooling or combining was necessary in 1959 to conform with the regulations. While the statement of claim merely alleged that it was not necessary when the notice was given on August 2,1955, the defence put in issue the question as to whether it was necessary at any time during the term of the lease and this must be determined. The lease, as stated, was proposed in its present form by Griffith and, in my opinion, if there were ambiguity in the language employed and doubt raised as to the meaning of such language, it should, if need be, be construed accordance with the maxim verba chartarum fortius accipiuntur contra proferentem (Leake, 9th ed., p. 158).

"This rule of construction is to be applied only when other rules of construction fail. In the present matter I find it difficult to understand in what circumstances it could have been contemplated that it was necessary to pool the respondent's land with the adjoining lands to conform with the regulations. There were no regulations in existence which affirmatively required any such pooling and it seems to me inconceivable that the Board would, of its own motion or on the application of either party, direct such pooling when the parties had themselves agreed upon the terms upon which such pooling should be brought about. If, as I think to be the case, what the proposed lessee intended to provide for was a provision for pooling when it was necessary to include the leased land with other lands in order to obtain a permit, if one were required, to produce gas or oil discovered on any part of the proposed unit, unfortunately the language employed is quite insufficient for such purpose. To assign any such meaning to the clause would be to read into it words that are not to be found in the clause as drafted.

"In my view, this portion of the language of para. 9 is to be construed literally in accordance with the plain meaning of the language employed and, as the appellants have not shown that in the circumstances pooling was necessary to conform to the regulations, the appeal must fail."

In the Kininmonth case the lessee commenced the drilling of well during the primary term. It had drilled to the Jumping Pound Sand which was dry and applied to the Oil and Gas Conservation Board for permission to plug back the well to complete it for the taking of production from the Cardium Sand. The application was approved by the Board, subject to the condition that the well should not be produced as a Cardium well until the lessee was entitled to produce from the entire spacing unit. However, a road ban was imposed and the lessee did not bring its heavy equipment in to finish the work until after the expiration of the primary term.

The sole point dealt with by the Appellate Division was the effect of the "force majeure" clause. The lessee argued that the road ban caused unavoidable interruption of drilling and that the Conservation Board requirements caused unavoidable interruption in production. The Court held that the lessee had not been active in trying to obtain a permit to take in its heavy machinery not withstanding the road ban, and also that it did not take steps available to obtain permission to produce from the well. They held that for these reasons the lessee could not rely on the drilling operations and subsequent production as extending the primary term.

In the Supreme Court of Canada a different point was taken. Martland J. referred back to his judgment in the Gunderson case where he said that the provision for the continuation of the term by reason of drilling operations only applied to drilling operations "after the expiration of 
the 5-year term." He said that the proviso takes effect only if the lease has been extended as a result of production and if when production ceases the lessee is then engaged in drilling operations. He held that the drilling commitment clause did not create any right to drill and continue drilling operations after the primary term but rather imposed a duty to drill within the primary term. Drilling operations under way at the end of the primary term did not continue the lease. He refers to divergence of the judicial views on the subject and concluded:

'However, irrespective of what construction may have been placed by Courts upon other leases, the essential task in the present case is to construe the terms of the lease which is in question. For the reasons already given, it is my view that there is no provision in it to enable the extension of its term beyond ten years, save only by the production of one of the substances from the land within and continuing beyond that period. Such production did not occur in the present case and, accordingly, in my opinion, the lease terminated at the end of its primary term."

The Kanstrup case also involved the pooling clause. Here a clause added by later agreement specifically contemplated the drilling of a well on a quarter section other than the Kanstrup section so that the difficulty in the Gunderson case was got around. However, the well which was drilled on the other quarter section was not produced at that time as there was no market and the lessee purported to keep the lease alive by paying the shut-in gas royalty, relying on the "force majeure" clause. The argument was that there was no market and that conservation regulations precluded the lessee from blowing gas into the air so that there could not be production. In this case, however, Martland J. said:

\footnotetext{
"The answer to this argument is that, while the clause postpones obligations, in certain events, it does not purport to modify the provisions of the habendum clause. That clause imposed no obligation upon the appellant to produce oil, gas or other minerals from the North West Quarter. It only provided that the primary term could be extended if oil, gas or other mineral was produced. If none of those substances were produced within the primary term, the lease terminated at the expiration of that term."
}

He also went on to hold that there is no question of relief against forfeiture since there was no breach of any obligation to produce. Acceptance of the royalty cheques did not work a waiver of forfeiture since there was no forfeiture but rather an automatic termination as was held in the Strohschein case.

This concludes the review of cases. It is now time to consider whether there are any conclusions to be drawn.

The principles enunciated by the Canadian courts are not unlike the principles enunciated by Summers. However, the Canadian courts have laid great emphasis on the literal construction of the document. While they have looked at the whole contract, it is difficult to avoid the conclusion that they have looked at it as a collection of words rather than as the embodiment of the arrangements adopted by the parties to achieve the objectives which they had in mind.

The Canadian cases do not show the application of any consistent "development" theory. The pattern of the cases appears to have been established by the Strohschein case and by the Gunderson case. One was a case where the lessee was trying to hold the lease without development; the second was a case where the lessee was trying to take advantage of earlier development on another property which had not conferred any 
benefit upon the property involved in the case. The courts might very well have departed from this pattern in cases where the lessee had invested very substantial sums of money in order to develop the property, and stood to lose the benefits resulting from such investment. These benefits accrued to the lessor who had not invested anything. However, in the Kanstrup and Kininmonth cases the Courts appear to have declined to depart from the pattern established by the earlier cases.

It is not easy to make a comparison between the judicial approach to the oil and gas lease and the judicial approach to other types of contract; and it is not easy to determine the nature of the inarticulate major premise upon which a judicial decision is based. However, the cases relating to other types of contract do appear to show somewhat more emphasis upon the circumstances surrounding the contract and the objectives intended to be achieved by the parties. This emphasis is not always apparent: the reasoning in the Northern Ontario case as quoted above is not unlike the literal approach adopted by Locke $J$. in the Gibbard case. The general pattern, however, does seem to include a greater degree of flexibility of interpretation in the cases relating to other contracts.

If there is any validity in these conclusions, is there any reason for the difference in approach?

"Let us for the moment forget that the defendants are a caput lupinum-a railway company" said Bramwell L.J. ${ }^{22}$ There may be some tendency to treat the oil operator as a latter day wolf's head. It is quite possible that there is present to the minds of the court a picture of an oil operator with experience in the industry, knowledge of the pitfalls and legal difficulties in the relationship of lessor and lessee, the assistance of agents skilled in the obtaining of leases, and the superior position of the large corporation. There may also be present to the mind of the court a picture of the landowner as someone who is not skilled in legal matters or in detecting the pitfalls in the relationship and who signs a document tendered to him more or less on trust and because it is a printed document. Such impressions would lead to a tendency to construe the lease in favour of the lessor, notwithstanding the remarks of Milvain $\mathbf{J}$. in the Crommie case. Probably the effect of such impressions can be overrated. It would be interesting to see whether clauses in a Crown lease, or in a lease tendered by some other lessor who is in a strong position, would be interpreted in the same way as the leases in the cases referred to above; certainly an approach which would tend to protect the Crown as a lessor against an oil operator who is a lessee on the basis of any of the rules of construction against the lessee would have its ludicrous aspects.

I think that there is a more important reason for the present judicial approach. It is that we are in a time of judicial conservatism. The Appellate Division draws very heavily on precedent and the Supreme Court of Canada does not readily break new ground. There does not seem to be any strong current of thought similar, for example, to that exemplified by Lord Denning in England, or to that exemplified by the decisions of the Supreme Court of the United States in constitutional questions. The oil and gas lease cases, if they show a conservative and literal approach to 
interpretation, appear to be a reflection of the general position of the courts. If this is so, it seems to follow that draftsmen of these documents will have to rely upon their resources of careful and lucid draftsmanship and not to count upon assistance from the courts.

To justify what is obviously a somewhat indecisive conclusion, I quote a passage from Cheshire and Fifoot: ${ }^{23}$

"The divergence of judicial opinion, in truth, reflects the speculative element inherent in the whole process of interpretation. Once more it is seen that neither 'the intention of the parties' nor 'the meaning of words' affords a practical and conclusive answer to the problem. On the one hand, it is not what the parties intended to write that matters but what they have in fact written; on the other hand, words possess no meaning in their own right but only when placed in a particular setting and read against all the relevant circumstances. To this setting and to those circumstances different minds will react in different ways. In most cases a court may choose between a literal and a liberal interpretation, and the choice will be largely a question of judicial temperament." 